\title{
Influence of Humic Substance in Solids on the Measurement of Oxygen-Consuming Organics of the Yellow River
}

\author{
X. H. Xia , L. H. Meng, and Z. F. Yang \\ School of Environment, Beijing Normal University / State Key Laboratory of Water Environmental Simulation, \\ Beijing 100875, P.R. China
}

\begin{abstract}
The Yellow River has a high content of solids. The influence of solids on the measurement of oxygen-consuming organics (OCOs) such as chemical oxygen demand $\left(\mathrm{COD}_{\mathrm{Mn}}\right)$ has aroused attentions in recent years. However, no research about effects of humic substance in solids on the determination of $\mathrm{COD}_{\mathrm{Mn}}$ has been reported. Experiments have been carried out to study the influence of humic substance in solids (Loess soil) on $\mathrm{COD}_{\mathrm{Mn}}$ in this research. Several significant results have arisen from the study. (1) The total $\mathrm{COD}_{\mathrm{Mn}}$ of water sample including liquid and solid phases increased significantly with the increase of solid content; the $\mathrm{COD}_{\mathrm{Mn}}$ of liquid phase of water sample under pre-treatment with acid (LPUPA) also increased significantly with the increase of solid

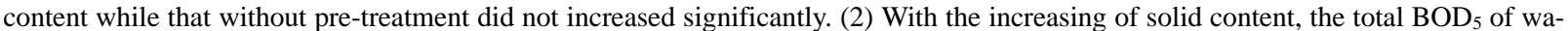
ter sample increased much slower than the total $C O D_{M n}$ and the $C O D_{M n}$ of LPUPA. (3) The humic substances in solids contributed greatly to the total $\mathrm{COD}_{\mathrm{Mn}}$ of water sample. When the solid contents were 7.5 and $15.0 \mathrm{~g} / \mathrm{L}$, the humic substances in solids accounted for $15.9 \%$ and $17.1 \%$ of the total $\mathrm{COD}_{\mathrm{Mn}}$ of water sample, respectively; fulvic acid-one of the main compositions of humic substance-contributed to $23.6 \%$ and $46.3 \%$ of the $\mathrm{COD}_{\mathrm{Mn}}$ of LPUPA, respectively. (4) The humic substances can hardly be biologically oxidized under natural conditions, the COD $\mathrm{Mn}_{\mathrm{n}}$ of LPUPA and the total $\mathrm{COD}_{\mathrm{Mn}}$ of water sample exaggerates the oxygen-consuming organic contamination of the Yellow River. Therefore, $\mathrm{COD}_{\mathrm{Mn}}$ was not suitable for being regarded as a parameter reflecting the pollution degree of OCOs in river water with a high solid content.
\end{abstract}

Keywords: $\mathrm{COD}_{\mathrm{Mn}}, \mathrm{BOD}_{5}$, humic substances, solids, Yellow River

\section{Introduction}

The Yellow River is the second longest river in China. It provides important water resources to the northern and northwestern regions of China. However, the water quantity is very scarce. In addition, deteriorating water quality of the Yellow River has been intensifying water shortage in the last decade (Zhao et al., 1998; Zhu et al., 1999; Xia et al., 2002); the functional water volume has thus been decreasing.

Oxygen-consuming organics (OCOs) is one of the main pollutants in the river. Chemical oxygen demand $\left(\mathrm{COD}_{\mathrm{Mn}}\right)$ and biological oxygen demand $\left(\mathrm{BOD}_{5}\right)$ have been used as the water quality parameters to reflect the pollution degree of OCOs. $\mathrm{COD}_{\mathrm{Mn}}$ refers to the amount of oxygen consumed when the organic matter in a given volume of water is chemically oxidized to $\mathrm{CO}_{2}$ and $\mathrm{H}_{2} \mathrm{O}$ by permanganate, a strong chemical oxidant. $\mathrm{BOD}_{5}$ refers to the amount of oxygen consumed when the organic matter in a given volume of water is biodegraded for five days. $\mathrm{COD}_{\mathrm{Mn}}$ is determined through oxidizing water sample with chemical oxidant while $\mathrm{BOD}_{5}$ with microorganism. Therefore, $\mathrm{BOD}_{5}$ directly reflects the pollution degree of OCOs while $\mathrm{COD}_{\mathrm{Mn}}$ indirectly reflects the pollution degree. They are coincident under normal conditions.

\footnotetext{
* Corresponding author: xiaxh@bnu.edu.cn
}

However, the measurement values of $\mathrm{COD}_{\mathrm{Mn}}$ did not coincide with those of $\mathrm{BOD}_{5}$ for the Yellow River. As the content of suspended solids is very high in the river, with an average suspended solids content of $28 \mathrm{~g} / \mathrm{L}$ (Zhao, 1998), the influence of solids on the measurement of OCOs, especially on $\mathrm{COD}_{\mathrm{Mn}}$ value, has aroused attention from the country in the last decade (Wang, 1995). For example, Li Qingfu and $\mathrm{Hu}$ Guohua has studied the relationship between $\mathrm{COD}_{\mathrm{Mn}}$ and solids ( $\mathrm{Li}$ and $\mathrm{Hu}, 1997 ; \mathrm{Hu}, 2000$ ), and the research results indicated that total $\mathrm{COD}_{\mathrm{Mn}}$ value of water sample including liquid and solid phases increased greatly with the solid content. Recently, Chen et al. have studied the influence of solid on COD values (Chen et al., 2003, 2004); based on the previous measurement data of $\mathrm{COD}_{\mathrm{Mn}}, \mathrm{BOD}_{5}$ and solid content of the river, they conducted correlation analysis and suggested that humic substance in solid was the key factor affecting the determination of $\mathrm{COD}_{\mathrm{Mn}}$ value.

In addition, during the past decades, many scientists around the world have carried out researches to study the influences of OCOs on dissolved oxygen (DO) and relationships between DO and BOD as well as between BOD and COD in waste and natural waters (Adrian and Sanders, 1998; Leu et al., 1998; Baker et al., 1999). Some researchers have studied methods for determination of COD in natural waters (Nabivanets et al., 2001; Udovichenko et al., 2001). 


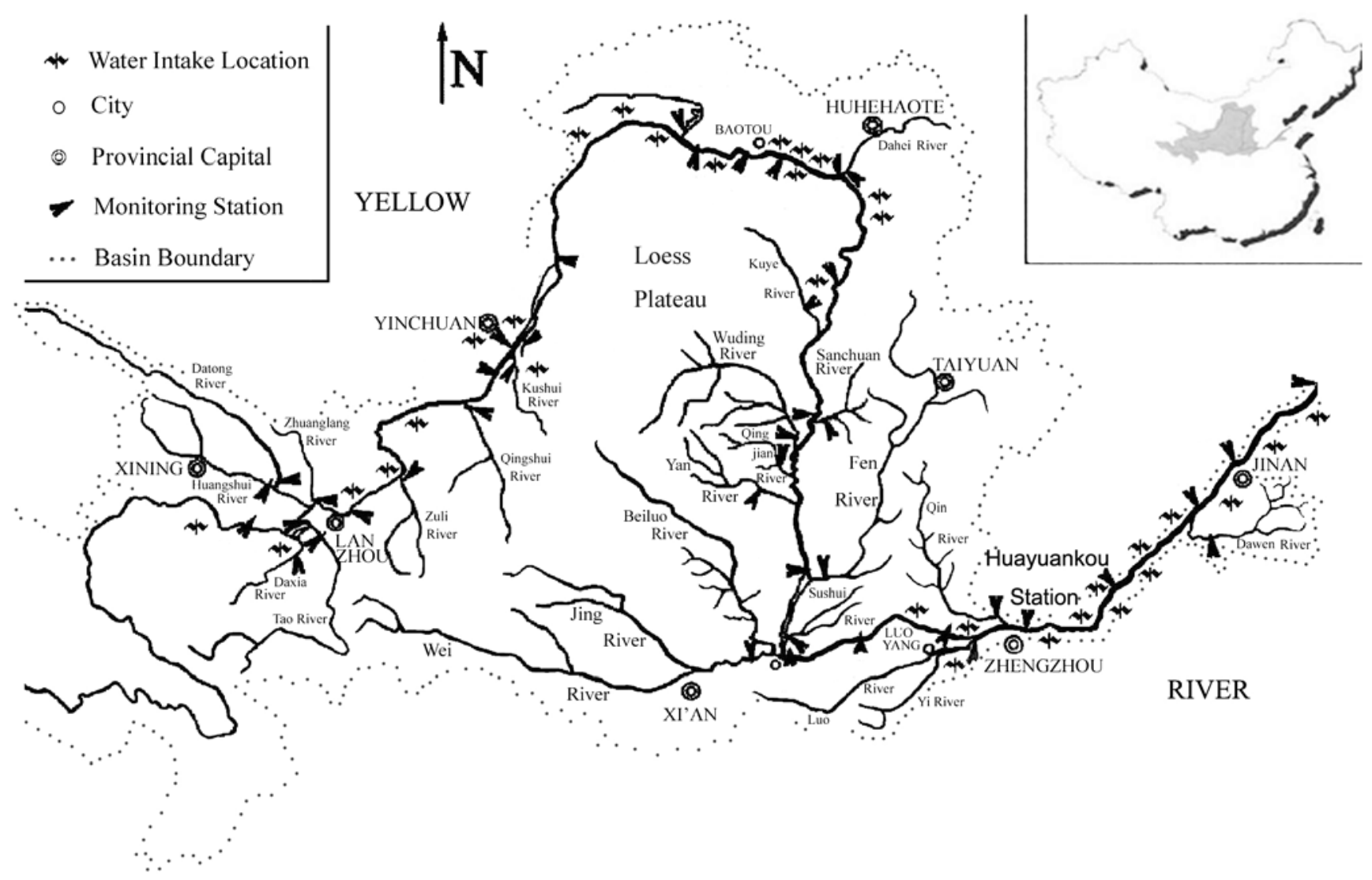

Figure 1. The Yellow River basin and the sampling locations.

However, no previous experimental research has been carried out to study the effects of humic substances on the measurement of OCOs of a river with high content of suspended solids. In addition, we don't know which part of humic substances in solid exerts influence on $\mathrm{COD}_{\mathrm{Mn}}$ and $\mathrm{BOD}_{5}$ values of a river, and in-depth analyses on strength of the influence are desired.

Therefore, this study is an extension of the previous effort, emphasizing on studying the influence of humic substances on the measurement of OCOs of the Yellow River through simulation experiments. The effects of each composition in humic substances will be analyzed; the contribution of the main influencing composition to $\mathrm{COD}_{\mathrm{Mn}}$ value in river water will be addressed. At the same time, biodegradation of humic substances in the solid will be studied to find out whether they fall within oxygen-consuming organics.

\section{Material and method}

\subsection{Sample Collection}

In this study, the sampling site of river water was located at the Huayuankou Hydrological Station which is in the middle reach of the Yellow River (Figure 1). Water samples were collected at a depth of $0.2 \mathrm{~m}$ in the central stream point on
November 19, 2002 and February 24, 2003. All samples were maintained at $4^{\circ} \mathrm{C}$ in a cooler, and then transported to the laboratory. After being centrifuged at $4000 \mathrm{rpm}$ for fifteen minutes (which was sufficient to remove all solids), the supernatant of the water sample was decanted for experiment work. Since solids in river water mainly come from the Loess Plateau which is located in the middle reach of the Yellow River, the solid (soil) sample site was located at Suide and Ansai of the plateau. Three kinds of soils were collected from Ansai, which included the soils without cultivation for 20, 8 and 2 years, respectively. Soil samples were collected at a depth of 0-20 cm on August 10, 2002. All the soil samples were air-dried and grounded, then sieved through $0.154 \mathrm{~mm}$ sieve for experimental analyses. The soil samples collected from Suide were used to study the effects of solids on the determination of $\mathrm{COD}_{\mathrm{Mn}}$ and $\mathrm{BOD}_{5}$ in water system; the soil samples collected from Suide and Ansai were used to study the biodegradation of humic substances in solids under natural conditions.

\subsection{Experimental Design}

(1) Effect of Solid Content on the Determination of $\mathrm{COD}_{\mathrm{Mn}}$ and $\mathrm{BOD}_{5}$

Since the solid content of river water at the Huayuankou 
Station ranged from 0.4 to $15.8 \mathrm{~g} / \mathrm{L}$, influences of $0,7.5,10$ and $15 \mathrm{~g} / \mathrm{L}$ solids on the measurement of $\mathrm{COD}_{\mathrm{Mn}}$ and $\mathrm{BOD}_{5}$ of river water samples were studied. For the influence of solids on $\mathrm{BOD}_{5}$, a known amount of soil sample was added to a series of $500 \mathrm{~mL}$ supernatant of river water sample, and stirred with magnetic agitator for an hour. Then $\mathrm{BOD}_{5}$ value of sample including liquid and solid phases was determined; after being centrifuged at $4000 \mathrm{rpm}$ for fifteen minutes, the supernatant of the water sample was decanted for the determination of $\mathrm{BOD}_{5}$ value.

In the regular measurement procedure of the Yellow River, acid was added to river water sample immediately after the collection; this was intended to prevent the organics from being biodegraded. Samples were then transported to the laboratory to determine $\mathrm{COD}_{\mathrm{Mn}}$ values of the supernatant and the sample including liquid and solid phases. Therefore, the $\mathrm{COD}_{\mathrm{Mn}}$ values of samples under pre-treatment with acid were also determined in this study to follow the routine measurement procedure of the river. For the influence of solids on $\mathrm{COD}_{\mathrm{Mn}}$, a known amount of soil sample was added to a series of $100 \mathrm{~mL}$ supernatant of river water sample, and sulfuric acid was added to the mixture of water and soil samples to make the $\mathrm{pH}$ value equal to 2.0. After that, the flasks were stirred with magnetic agitator for an hour. Then total $\mathrm{COD}_{\mathrm{Mn}}$ value of sample including liquid and solid phases was determined; after being centrifuged at $4000 \mathrm{rpm}$ for fifteen minutes, the supernatant of the water sample was decanted for the determination of $\mathrm{COD}_{\mathrm{Mn}}$ value. In addition, $\mathrm{COD}_{\mathrm{Mn}}$ values of samples without pre-treatment with acid were also determined in this research to study the effect of pre-treatment with acid on the determination of $\mathrm{COD}_{\mathrm{Mn}}$. Each experimental set was conducted in duplicate with a set of controls. The control experiments were carried out with water samples without addition of soil samples.

(2) Contribution of Humic Substances in Solids to $\mathrm{COD}_{\mathrm{Mn}}$ Value

Humic substances extracted from 7.5 and 15 g soil samples were added to $1000 \mathrm{~mL}$ supernatant of river water sample, respectively, and stirred with magnetic agitator for an hour. $\mathrm{COD}_{\mathrm{Mn}}$ values of the samples were then measured and $\mathrm{COD}_{\mathrm{Mn}}$ value produced from humic substances could then be determined. Each experimental set was conducted in duplicate with a set of controls. The control experiments were carried out with water samples without addition of humic substances.

(3) Contribution of Fulvic Acid in Humic Substances of Solids to $\mathrm{COD}_{\mathrm{Mn}}$ Value

Fulvic acid extracted from 7.5 and 15 g soil samples were added to $1000 \mathrm{~mL}$ supernatant of river water samples, respectively, and stirred with magnetic agitator for an hour. $\mathrm{COD}_{\mathrm{Mn}}$ values of the samples were then measured and $\mathrm{COD}_{\mathrm{Mn}}$ produced from fulvic acid could then be determined. Each experimental set was conducted in duplicate with a set of controls. The control experiments were carried out with water samples without addition of fulvic acid.

\section{(4) Biodegradation of Humic Substances}

Natural river water and soil samples were used as media for biodegradation experiments. A total amount of 7.5 and 15 g soil samples were added to a series of glass flasks that contained $1000 \mathrm{~mL}$ supernatant of river water samples, respectively. Then the flasks were covered by eight layers of gauze to prevent outside bacteria from entering them. They were cultivated in the dark for five days at $25^{\circ} \mathrm{C}$ with a HZQ-F incubator under constant shaking (150 strokes/minute) to promote the growth of indigenous microorganisms. Humic substances in samples including liquid and solid phases were measured before and after cultivation, respectively. Then the biodegradation efficiency of humic substances within five days was determined. Each experimental set was conducted in duplicate with a set of controls. The control experiments were carried out with the sterilized water and soil samples, and microbial activities were inhibited through mercuric chloride.

\subsection{Chemical Analysis}

The humic substances in solids were extracted by sodium pyrophosphate-sodium hydroxide (Wen et al., 1984). The humic substances in river water were extracted by XAD-8 resin and then eluted with sodium hydroxide solution (Tao et al., 1988). Fulvic acid was obtained after the acidification, filtration and purification of humic substances (Nanjing Institute of Soil Science, 1978). The obtained humic substances and fulvic acid were determined through Phoenix 8000 TOC instrument. The liquid phase of water samples were obtained after centrifugation with LD5-2A centrifugal machine. $\mathrm{COD}_{\mathrm{Mn}}$ values of samples were measured by potassium permanganate with acidity (Xi et al., 2004). BOD $_{5}$ of samples were measured at $20^{\circ} \mathrm{C}$ with an $\mathrm{AL}_{2} 20 \mathrm{BOD}_{5}$ machine made in WTW Company of Germany.

Samples were collected from the river for two times, as the results of these two samples were similar, only one set of data were shown in this paper. Each experimental set was conducted in duplicate; the relative standard deviation was less than $5 \%$.

\section{Results and Discussions}

\subsection{Water Sample Chemistry and Humic Substance Analysis}

The ion concentrations in water samples were determined with ion chromatography. As shown in Table 1, the total ion concentration in the water sample was $532.4 \mathrm{mg} / \mathrm{L}$. The $\mathrm{pH}$ value was 8.08, indicating that the water was slightly alkaline. The contents of fulvic acid and humic substances in soil sample were $0.28 \%$ and $0.76 \%$, respectively. Therefore, the content of fulvic acid in humic substances was $36.8 \%$. The chemical and physical characteristic of the solids in the river was shown in the previous study (Xia et al., 2004). 
Table 1. Chemical Composition of the Water Sample Collected on November 19, 2002 (mg/L), except for the $\mathrm{pH}$ )

\begin{tabular}{lllllllllll}
\hline $\mathrm{pH}$ & $\mathrm{DO}$ & $\mathrm{COD}_{\mathrm{Mn}}$ & $\mathrm{BOD}_{5}$ & $\mathrm{NH}_{4}^{+}-\mathrm{N}$ & $\mathrm{Ca}^{2+}$ & $\mathrm{Mg}^{2+}$ & $\mathrm{K}^{+}$ & $\mathrm{Cl}^{-}$ & $\mathrm{SO}_{4}{ }^{2+}$ & $\mathrm{HCO}_{3}^{-}$ \\
\hline 8.08 & 10.0 & 8.5 & 4.0 & 2.34 & 66.7 & 18.2 & 71.4 & 82.8 & 106.5 & 184.5 \\
\hline
\end{tabular}

\subsection{Influence of Solids on $\mathrm{COD}_{\mathrm{Mn}}$}

(1) Water Sample without Pre-treatment with Acid

As shown in Figure 2, the total $\mathrm{COD}_{\mathrm{Mn}}$ of water sample including liquid and solid phases increased with the content of solids. When the solid contents were $0,7.5,10$, and $15 \mathrm{~g} / \mathrm{L}$, $\mathrm{COD}_{\mathrm{Mn}}$ values were $8.5,41.2,60.8$, and $85.6 \mathrm{mg} / \mathrm{L}$, respectively.

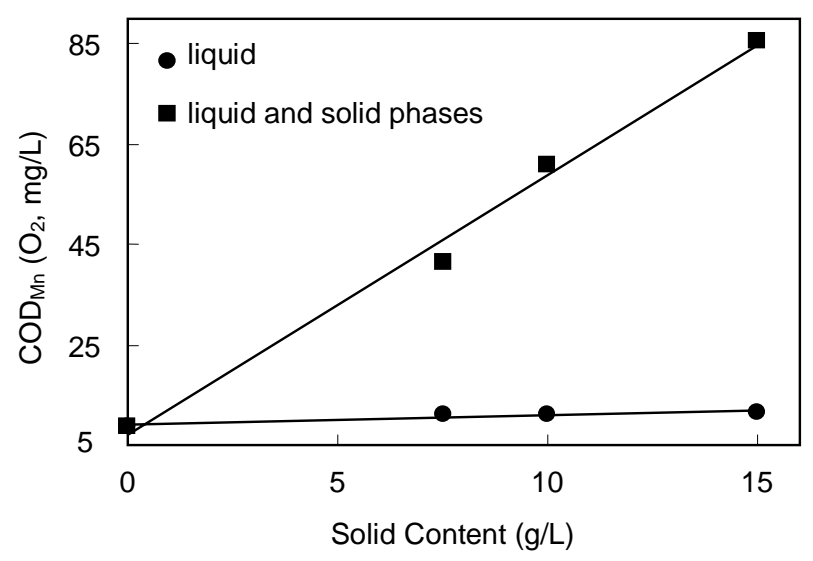

Figure 2. Effect of solids on $\mathrm{COD}_{\mathrm{Mn}}$ value in water system (without pre-treatment with acid).

$\mathrm{COD}_{\mathrm{Mn}}$ value of supernatant of water sample increased slightly with the content of solids. When the solid content increased from 0 to 7.5 and to $15 \mathrm{~g} / \mathrm{L}, \mathrm{COD}_{\mathrm{Mn}}$ value of the supernatant only increased from 8.5 to 11.0 and to $11.3 \mathrm{mg} / \mathrm{L}$, respectively. This experimental result is consistent with those obtained by Li and Hu (1997).

\section{(2) Water Sample under Pre-treatment with Acid}

As shown in Figure 3, with the increasing of solid content, the increasing rate of $\mathrm{COD}_{\mathrm{Mn}}$ value of liquid phase of water sample under pre-treatment with acid (LPUPA) was much higher than that without pre-treatment with acid (LPWPA). When the increment of solid content was $1 \mathrm{~g} / \mathrm{L}$, the increments of $\mathrm{COD}_{\mathrm{Mn}}$ values of LPUPA and LPWPA were 1.0 and $0.2 \mathrm{mg} / \mathrm{L}$, respectively.

\section{(3) Influence of Solids on $\mathrm{BOD}_{5}$}

As shown in Figure 4, both total $\mathrm{BOD}_{5}$ of water sample including liquid and solid phases and $\mathrm{BOD}_{5}$ of liquid phase of water sample increased with the solid content; the increasing rate of the former was much higher than that of the latter. As shown in Figure 5, however, with the increasing of solid content, the increasing rate of total $\mathrm{BOD}_{5}$ of water sample was much lower than that of the total $\mathrm{COD}_{\mathrm{Mn}}$ of water sample and $\mathrm{COD}_{\mathrm{Mn}}$ of LPUPA. The increment of solid content of $1 \mathrm{~g} / \mathrm{L}$ could lead to the increment of total $\mathrm{COD}_{\mathrm{Mn}}$ of water sample of $5.14 \mathrm{mg} / \mathrm{L}$ and $\mathrm{COD}_{\mathrm{Mn}}$ of LPUPA of $0.97 \mathrm{mg} / \mathrm{L}$; while could lead to the increment of total $\mathrm{BOD}_{5}$ of only $0.53 \mathrm{mg} / \mathrm{L}$.

As above mentioned, $\mathrm{COD}_{\mathrm{Mn}}$ value of water sample including liquid and solid phases increased greatly with the increasing of solid content. This was due to the fact that the organics and other reducing substances existing in solids could be oxidized by potassium permanganate. The reason for the increasing of $\mathrm{COD}_{\mathrm{Mn}}$ value of LPUPA with solid content was that some substances in solids could be dissolved in acid and oxidized by potassium permanganate. Since $\mathrm{BOD}_{5}$ value reflects the oxygen quantity consumed by organics biodegradation, then according to the above experimental results, we can deduce that there are some substances in solids, which can be dissolved in acid and oxidized by chemical oxidant but can hardly be decomposed by microorganism under natural aquatic conditions.

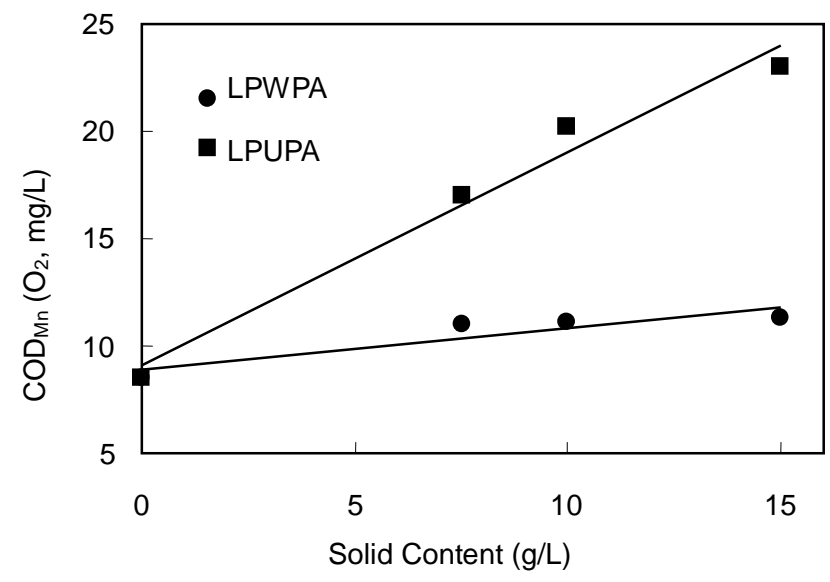

Figure 3. Comparison between effects of solids on $\mathrm{COD}_{\mathrm{Mn}}$ values of LPUPA and LPWPA.

Humic substances are a naturally occurring mixture of organic compounds, which is slightly dissolved in water. According to its dissolution in acid and alkali, it can be divided into humic acid, fulvic acid and humus. The fulvic acid can be dissolved in acid and alkali; humic acid can only be 
dissolved in alkali and humus can not be dissolved in acid or alkali. In addition, some research results indicated that humic substances is one kind of stable organics; it can hardly be degraded by microbes in natural system (Douglas et al., 1995; Sudha et al., 1995; Xiong et al., 1998; Huck, 1999). Therefore, we conjectured that the substances existing in solids, which can be oxidized by potassium permanganate and partly dissolved in acid but can hardly be biodegraded, is humic substances.

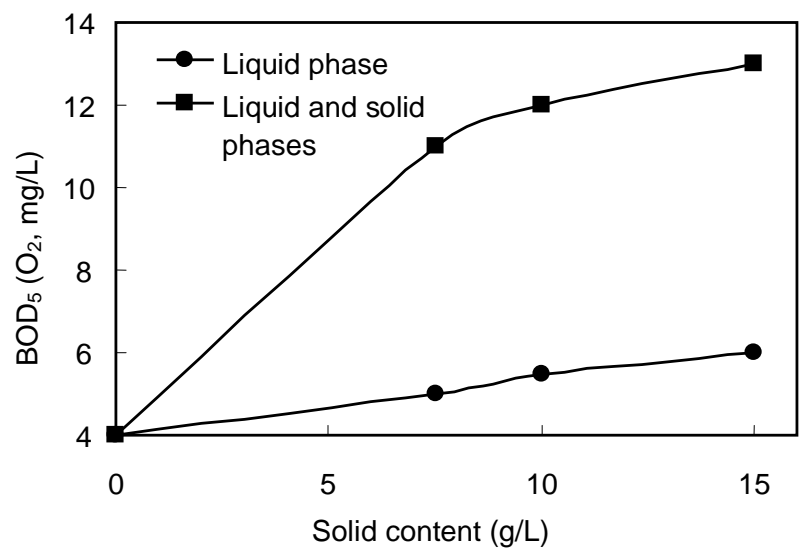

Figure 4. Relationship between solid content and $\mathrm{BOD}_{5}$ values.

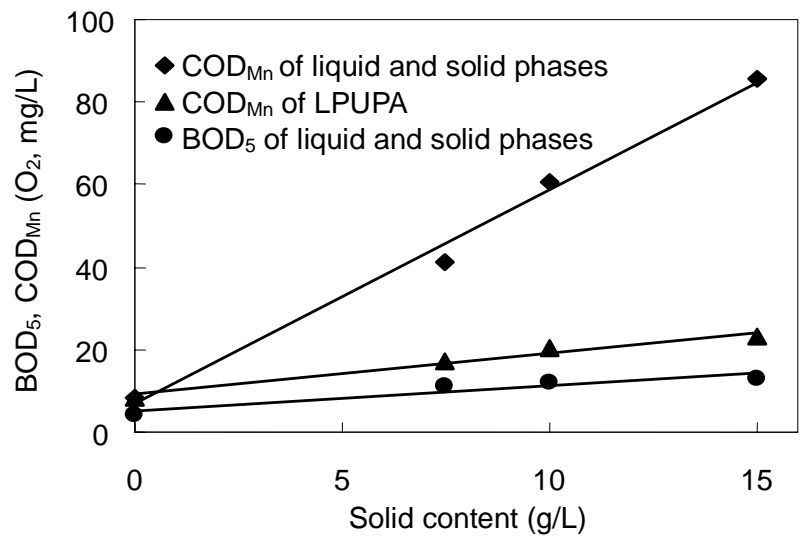

Figure 5. Comparison among effects of solids on $\mathrm{BOD}_{5}$ and $\mathrm{COD}_{\mathrm{Mn}}$ values.

\section{(4) $\mathrm{COD}_{\mathrm{Mn}}$ of Humic Substances in Solids}

When the solid content was $7.5 \mathrm{~g} / \mathrm{L}, \mathrm{COD}_{\mathrm{Mn}}$ value of humic substances in solids was $6.8 \mathrm{mg} / \mathrm{L}$. It contributed to $15.9 \%$ of $\mathrm{COD}_{\mathrm{Mn}}$ value $(42.9 \mathrm{mg} / \mathrm{L})$ of water sample including liquid and solid phases. When the solid content was 15.0 $\mathrm{g} / \mathrm{L}, \mathrm{COD}_{\mathrm{Mn}}$ value of humic substances in solids was 14.6 $\mathrm{mg} / \mathrm{L}$. It contributed to $17.1 \%$ of $\mathrm{COD}_{\mathrm{Mn}}$ value $(85.6 \mathrm{mg} / \mathrm{L})$ of water sample including liquid and solid phases.
As shown in Figure 3, $\mathrm{COD}_{\mathrm{Mn}}$ value of LPUPA increased much more greatly than that of LPWPA with solid content. The contents of fulvic acid and humic substances in solids were $0.28 \%$ and $0.76 \%$, respectively. Since fulvic acid is an organic component that can be dissolved in acid, we deduced that the notable increasing of $\mathrm{COD}_{\mathrm{Mn}}$ value of LPUPA with solid content was caused by fulvic acid in solids. According to the experimental results, when the solid contents were 7.5 and $15.0 \mathrm{~g} / \mathrm{L}$, the $\mathrm{COD}_{\mathrm{Mn}}$ values caused by fulvic acid in solids and the supernatant of river water sample were 12.5 and 19.2 $\mathrm{mg} / \mathrm{L}$, respectively; the $\mathrm{COD}_{\mathrm{Mn}}$ values of LPUPA were 17.0 and $23.1 \mathrm{mg} / \mathrm{L}$, respectively. The $\mathrm{COD}_{\mathrm{Mn}}$ value of the supernatant of river water sample was $8.5 \mathrm{mg} / \mathrm{L}$. Therefore, the $\mathrm{COD}_{\mathrm{Mn}}$ values of fulvic acid in solids contributed to $23.6 \%$ and $46.3 \%$ of those of LPUPA, respectively.

As shown above, the $\mathrm{COD}_{\mathrm{Mn}}$ values of fulvic acid in solids and the supernatant of river water were slightly less than those of LPUPA. This implied that there was other substances existed in solids which could be dissolved in acid and oxidized by chemical oxidant. The content of total organics in soil was $1.12 \%$. As the content of humic substances in soil was $0.76 \%$, the content of organics other than humic substances was $0.36 \%$, which contributed to $32.1 \%$ of the total organics in soil. This kind of organics other than humic substance could also be oxidized by chemical oxidant, which led to the above phenomena that the $\mathrm{COD}_{\mathrm{Mn}}$ values of fulvic acid in solids and the supernatant of river water were slightly less than those of LPUPA.

\section{(5) Biodegradation of Humic Substances in Soil}

A total amount of 7.5 and $15 \mathrm{~g}$ soil samples were added to $1000 \mathrm{~mL}$ supernatant of river water samples, respectively, and cultivated for five days at $25^{\circ} \mathrm{C}$. The experimental results are shown in Figure 6. The sequence of humic substance content in soils was: soil without cultivation for 20 years $>$ soil without cultivation for 8 years $>$ soil without cultivation for 2 years. When the solid content was $7.5 \mathrm{~g} / \mathrm{L}$, the biodegradation rate of humic substance in solids ranged from $1.64 \%$ to $6.13 \%$; when the solid content was $15.0 \mathrm{~g} / \mathrm{L}$, it ranged from $1.98 \%$ to $5.39 \%$. Therefore, humic substances in the soil samples could hardly be biodegraded in natural conditions; that is to say, they could hardly consume oxygen in river water.

The humic substances with the content of $0.76 \%$ in solids (Loess soil) contributed greatly to the total $\mathrm{COD}_{\mathrm{Mn}}$ of water sample. When the solid contents were 7.5 and $15.0 \mathrm{~g} / \mathrm{L}$, the humic substances in solids accounted for $15.9 \%$ and $17.1 \%$ of the total $\mathrm{COD}_{\mathrm{Mn}}$ of water sample, respectively. In addition, as one of the main components of humic substances, fulvic acid can be dissolved in acid. Since acid is added to river water samples to prevent organic pollutants from being biologically oxidized before the determination of $\mathrm{COD}_{\mathrm{Mn}}$, fulvic acid existing in solids will be dissolved in water phase which is used to measure the $\mathrm{COD}_{\mathrm{Mn}}$ of river water sample. $\mathrm{COD}_{\mathrm{Mn}}$ value of LPUPA increased greatly with solid content. When the solid contents were 7.5 and $15.0 \mathrm{~g} / \mathrm{L}$, the $\mathrm{COD}_{\mathrm{Mn}}$ values of fulvic acid in solids contributed to $23.6 \%$ and $46.3 \%$ of those 

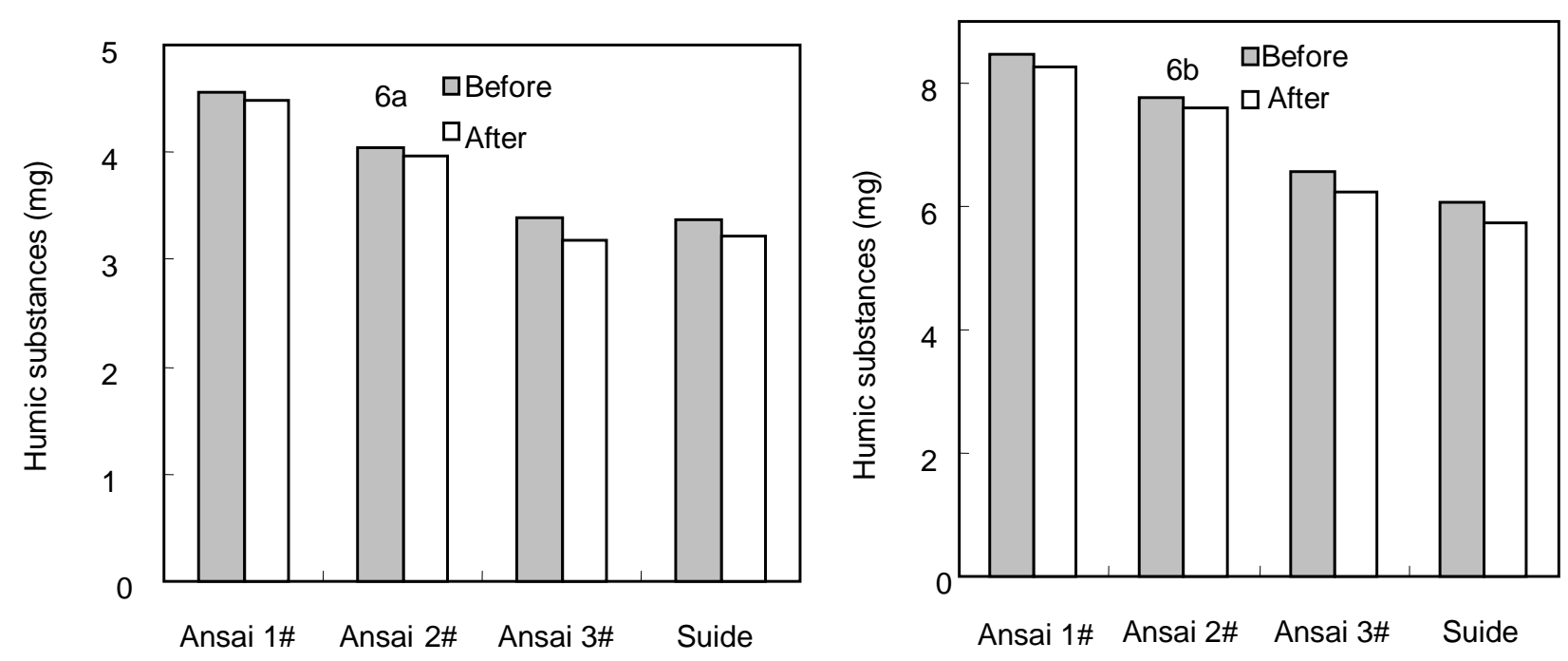

Figure 6. Biodegradation efficiencies of humic substances in soils collected from different places (6a: solid content was 5.0 $\mathrm{g} / \mathrm{L}$ in water system; 6b: solid content was $10.0 \mathrm{~g} / \mathrm{L}$ in water system. Ansai 1\#, 2\# and 3\# refer to soil without cultivation for 20, 8 and 2 years, respectively).

of LPUPA, respectively. Based on the above-mentioned, the humic substances existing in solids can hardly be biologically oxidized in natural conditions. $\mathrm{COD}_{\mathrm{Mn}}$ values of liquid phase and the whole water samples including liquid and solid phases influenced by the solids will exaggerate the OCOs pollution degree of the Yellow River; it is not suitable for being regarded as a water quality parameter reflecting the pollution degree of OCOs of the river.

\section{Conclusions}

Experiments have been carried out to study the influences of humic substances in solids (Loess soil) on the measurement of oxygen-consuming organics of the Yellow River in this research. The following results have arisen from the study:

(1) The total $\mathrm{COD}_{\mathrm{Mn}}$ of water sample including liquid and solid phases increased significantly with the solid content; the $\mathrm{COD}_{\mathrm{Mn}}$ of LPUPA also increased significantly with the increase of solid content while that of LPWPA did not increased significantly.

(2) With the increase of solid content, the increasing rate of total $\mathrm{BOD}_{5}$ of water sample was much lower than those of $\mathrm{COD}_{\mathrm{Mn}}$ of LPUPA and total $\mathrm{COD}_{\mathrm{Mn}}$ of water sample.

(3) The humic substances with the content of $0.76 \%$ in solids (Loess soil) contributed greatly to the total $\mathrm{COD}_{\mathrm{Mn}}$ of water sample. When the solid contents were 7.5 and $15.0 \mathrm{~g} / \mathrm{L}$, the humic substances in solids accounted for $15.9 \%$ and $17.1 \%$ of the total $\mathrm{COD}_{\mathrm{Mn}}$ of water sample, respectively; fulvic acid - one of the main components of humic substance - contributed to $23.6 \%$ and $46.3 \%$ of the $\mathrm{COD}_{\mathrm{Mn}}$ of LPUPA, respectively.

Since the humic substances can hardly be biologically oxidized under natural conditions, the $\mathrm{COD}_{\mathrm{Mn}}$ of LPUPA and the total $\mathrm{COD}_{\mathrm{Mn}}$ of water sample exaggerated the oxygen-consuming organic contamination of the Yellow River. Therefore, $\mathrm{COD}_{\mathrm{Mn}}$ is not suitable for being regarded as a parameter reflecting the pollution degree of OCOs in river water with a high solid content.

Acknowledgments. The study was supported by the National Natural Science Foundation of China (No. 50239010 and No. 40201046).

\section{References}

Adrian, D.D. and Sanders, T.G. (1998). Oxygen sag equation for second-order BOD decay. Water Res., 32(3), 840-848.

Baker, J.R., Milke, M.W. and Mihelcic, J.R. (1999). Relationship between chemical and theoretical oxygen demand for specific classes of organic chemicals. Water Res., 33(2), 327.

Chen, J.S., He, D.W. and Zhang, Y. (2003). Can COD values reflect the actual pollution degree of river water of the Yellow River. Environ. Chem., 6, 611-614 (in Chinese).

Chen, J.S., Zhang, Y., Yu, T. and He, D.W. (2004). The solubility and biodegradability of humic substances of solids of the Yellow River. ACTA Scientiae Circumstantiae, 1, 1-5 (in Chinese).

Goel, S., Hozalski, R.M. and Bouwer, E.J. (1995). Biodegradation of NOM: effect of NOM source and ozone dose. J. Am. Water Works Assoc., 87(1), 90-105.

Hong, Y., Hong, G.Z. and Wang, J.L. (2001). Measurement technique of COD of the Yellow Rive. Yellow River, 23(3), 18-20 (in Chinese).

Hu, G.H. (2000). An experimental study on effects of solids on $\mathrm{COD}_{\mathrm{Mn}}$ of the Yellow River. Yellow River, 22(3), 17-18 (in Chinese).

Huck, P.M. (1999). Development of a framework for quantifying the removal of humic substances by biological filtration. Water Sci. Technol., 40(9), 149-156. 
Leu, H.G., Lee, C.D. and Ouyang, C.F.A. (1998). Modified water quality model for predicting BOD and DO variations in a shallow polluted channel. Environ. Technol., 19(9), 933.

Li, Q.F. and Hu, G.H. (1997). Water quality modeling of Meng-Hua section of the Yellow River-forecasting model of $\mathrm{COD}_{\mathrm{Mn}}$ for a river with high content of solids. Water Resour. Preserv., 1, 16-19 (in Chinese).

Li, T.J., Zheng, Y.S. and Wang, Y. (1983). Soil Geography, Higher Education Press, Beijing, pp. 27-29 (in Chinese).

Nabivanets, B.I., Linnik, P.N. and Udovichenko, V.V. (2001). Methods for determination of chemical oxygen demand in the natural waters. Hydrobiol. J., 37(5), 87-104.

Nanjing Institute of Soil Sciences (1978). Chemical and Physical Analyses of Soils, Shanghai Science and Technology Publisher, Shanghai, pp. 136-140 (in Chinese).

Owen, D.M., Amy G.L., Chowdhury, Z.K., Paode, R., Mccoy, G. and Viscosil, K. (1995). NOM characterization and treat ability. $J$. Am. Water Works Assoc., 87(1), 46-63.

Tao, S. and Chen, J.S. (1988). The origin, content and regional distribution of humic substances in river water of the eastern rivers in china. ACTA Scientiae Circumstantiae, 8, 286-293 (in Chinese).

Udovichenko, V.V., Nabivanets, V.I. and Sukhin, V.V. (2001). Accelerated method for the determination of chemical oxygen demand in the natural waters. Hydrobiol. J., 37(2), 100-107.

Wang, J.L. (1995). Effects of sample conservation method on the measurement of COD and total iron, in Water Resources Conservation Agency of the Yellow River, Selected Assembly of Scientific Achievement and Study on Water Resources Conservation of the Yellow River, Yellow River Publishing House of the Water Resources, Zhengzhou, pp. 78-79(in Chinese).

Xi, D.L., Sun, Y.S. and Liu, X.Y. (2004). Environmental Monitoring, Higher Education Press, Beijing (in Chinese).

Xia, X.H., Zhou, J.S. and Yang, Z.F. (2002). Nitrogen contamination in the Yellow River basin of China. J. Environ. Qual., 31, 917-925.

Xia, X.H., Yang, Z.F., Huang, G.H., et al. (2004). Nitrification in natural waters with high suspended-solid content-A study for the Yellow River. Chemosphere, 57, 1017-1029.

Xiong, X.Y., Huang, T.L. and Yu, J.T. (1998). An experimental study of ozonization of humic acid in water and its biological degradability. Environ. Eng., 16(6), 7-11 (in Chinese).

Yan, E. and Sun, W.F. (2000). Research status of analytical chemistry of humic substances in soil. J. Qinghai Univ. (Natural Sciences), 18 (5), 17-22 (in Chinese).

Zhao, P.L., Shen, X.C. and Xia, J. (1998). The Effect of Sediment on Water Quality and Water Pollution Control in Key River Sections in the Yellow River, Yellow River Publishing House of the Water Resources, Zhengzhou (in Chinese).

Zhu, X.Y. and Zhang, X.C. (1999). Research on Water Resource Change of the Yellow River, Yellow River Publishing House of the Water Resources, Zhengzhou (in Chinese). 